\title{
INFUSORIAL CONCENTRATION IN RUMEN FLUID OF RED DEER, FALLOW DEER, ROE DEER AND MOUFFLON
}

\author{
J. KAMLER \\ Institute of Vertebrate Biology, Academy of Sciences of the Czech Republic, Brno
}

Received May 10, 1999

Accepted October 25, 1999

Abstract

Kamler J.: Infusorial Concentration in Rumen Fluid of Red Deer, Fallow Deer, Roe Deer and Moufflon. Acta Vet. Brno, 1999, 68: 247-252.

Infusorial concentrations in rumen fluid of red deer, fallow deer, roe deer and moufflon indigenous of North and South Moravia were studied during the vegetation period and during the winter season. The total number of 178 shot animals was examined. Concentration of infusoria was determined by counting in Fuchs-Rosenthal counting chamber. During the vegetation period, infusorial concentrations per $\mathrm{ml}$ of rumen fluid were within the range of $547-927 \times 10^{3}$ in red deer, $118-785 \times 10^{3}$ in roe deer, $257-726 \times 10^{3}$ in fallow deer and $385-865 \times 10^{3}$ in moufflon. In the winter season, infusorial concentrations found in all of the four studied game species were significantly lower in comparison to the vegetation period. The type of the locality influenced infusorial concentrations only in the winter. Sex or age of the examined animals had no influence on infusorial concentrations.

Infusoria, rumen, free-living ruminants, feeding type

The processes taking place in rumen play a key role in nutrition of ruminants. Here the ingested food is subject to intensive microbial decomposition, and only the products of microorganism activity are utilized for nutrition of the ruminant (B artoš 1978; Jelínek et al. 1989; Dvořák 1994 and others). Hence we speak of two-phase digestion of ruminants: 1. microbial (ruminal) digestion

2. enzymatic (postruminal) digestion

Bacteria, infusoria and rumen fungi are present in rumen. Species composition of rumen microbial population is relatively stable, although some differences between individual game species were found. The rumen microorganisms adhere to feed particles, to rumen epithelial cells or they are found free in the rumen fluid. The numbers and species composition of microorganisms determining the course of digestive processes in rumen are highly variable, depending on a variety of factors, the most important of which is the type of feed (fermentative substrate for microorganisms). Since a ruminant is dependent on the microorganism activity, any decrease of their number causes a change of the digestive processes and in consequence, inadequate nutrition.

The rumen infusoria have been studied mostly in domesticated ruminants. Data on concentration, species composition and significance of rumen infusoria can be found in Crha (1969), Holub et al. (1969), Bergner and Ketz (1975), Church (1976), Dvořák (1994) and others.

The information on the ruminal fauna in free-living game species is relatively limited and often coming from different environmental conditions. For example, Enzinger and Hartfiel (1998) compared infusoria in some domestic and free-living species. Dehority (1997) monitored infusorial concentrations in rumen of red deer. Szakács et al. (1995ab) studied the influence of nutrition on digestive processes and microorganism population in red deer under experimental conditions. Kubíková (1935), Sládeček

Address for correspondence:

Ing. Jiří Kamler, Ph.D.

Institute of Vertebrate Biology AV CR

60365 Brno, Czech Republic hone: +420543422514

Fax: +4205 43211246

http://www.vfu.cz/acta-vet/actavet.htm 
(1947), Crha (1972) and others dealt with rumen infusoria in the Czech Republic environment. Crha (1972) described infusorial concentration and species composition in rumen of fallow deer shot during winter in Náměšt game preserve. Crha et al. (1985) monitored rumen infusoria in chamois shot during winter in Jeseníky mountains, and reports on species composition of infusoria in rumen fluid of red deer, fallow deer, roe deer and chamois (Crha 1990).

The aim of the present study was to evaluate infusorial concentrations in rumen of red deer, fallow deer, roe deer and moufflon and their variability in response to game species, sex and age of the animal and season.

The hypothesis that rumen infusoria concentration in ruminants depends mostly on type of the ingested food, was tested. The infusorial concentration was expected to vary between different feeding types, different seasons and between game living in areas with different food supply, and not to vary between sexes and age classes of the same species coming from the same locality.

\section{Materials and Methods}

Characteristics of the localities

The data on digestive tract of red deer, fallow deer, roe deer and moufflon were collected in three localities in Moravia.

Locality No. 1 lies 2 km north from Staré Město pod Sněžníkem at altitude of 800 - 1000 metres above sea level and is a part of a vast forest complex. In this locality the samples of red deer and roe deer were obtained. According to the climate, the locality can be classified as $\mathrm{C} 1$. Coniferous stands are prevalent in this region. In these conditions with minimal broad-leaved undergrowth, grazing opportunities for the game are extremely limited. Agriculture in the region is confined to grazing of grasslands with no other maintenance. During the last few years, approximately 20 red deer per 1000 hectares per year were shot in this area. In the winter season the game is fed in large-sized feed racks, primarily on roughage. The hay is of poor to average quality, obtained from the surrounding mountain meadows. The use of silage from plastic-wrapped bales has been introduced.

Locality No. 2 lies in hills at the foot of the Jeseníky mountains near Šumperk. The climatic classification of the region is B5. It is a typical submontane landscape where small complexes of pure spruce and mixed forests alternate with areas of fields, meadows and pastures. The land is exploited for agriculture and game can graze on both permanent grasslands and field crops. Feeding opportunities for free-living ruminants are quite good due to the landscape diversity. Game care is limited mostly to traditional feeding on grain feed and roughage, especially during the winter months. From this locality the samples of fallow deer, roe deer and moufflon were obtained.

Locality No. 3 lies near Brno. Fallow deer, roe deer and moufflon were obtained from here. The climatic classification of the area is A3. Both broad-leaved and coniferous forests are present, and the game may graze on nearby meadows and fields. Feeding opportunities are very good all year round due to excellent carrying capacity of the environment for all of the studied ruminant game species. During the winter season, game is regularly fed on grain feed and roughage.

Materials

A total of 178 animals was examined, 60 of which were red deer, 28 fallow deer, 65 roe deer and 25 moufflons (Table 1).

Table 1

Numbers of samples (used for analyses) from individual localities

\begin{tabular}{|l|r|r|r|r|r|r|r|r|}
\hline Species & \multicolumn{2}{|c|}{ CE } & \multicolumn{2}{c|}{ DD } & \multicolumn{3}{c|}{ CC } & \multicolumn{2}{c|}{ OM } \\
\hline Sex & M & F & M & F & M & F & M & F \\
\hline Locality 1 & 20 & 40 & 0 & 0 & 19 & 16 & 0 & 0 \\
\hline Locality 2 & 0 & 0 & 12 & 11 & 11 & 13 & 6 & 8 \\
\hline Locality 3 & 0 & 0 & 3 & 2 & 6 & 0 & 7 & 4 \\
\hline
\end{tabular}

Abbreviations of Latin names are used in tables (CE - red deer, DD - fallow deer, CC - roe deer and OM moufflon). Game was divided into following 3 age categories according to age:

Red deer: 1. category $1-2$ years Roe deer: 1. category 1 year

2 . category $3-5$ years

3 . category $>6$ years

2 . category $2-3$ years

3 . category $>4$ years 
To study the influence of season, samples were sorted into two groups:

1. samples obtained during the vegetation period (16. 5.-31. 10.)

2. samples obtained during the winter season (1. 11-31. 1.).

The results of roe deer rumen contents analysis were used to evaluate the influence of the environment (amount

of material from other game species was not sufficient). The samples were divided into two groups by origin:

1. samples from locality No.1 (referred to as CCh)

2. samples from other localities (referred to as $\mathrm{CCn}$ ).

Methods

The samples for evaluation of rumen fluid infusorial concentrations were obtained from freshly shot red deer, fallow deer, roe deer and moufflon. The rumen was cut open as soon as possible after the animal was killed (within $30 \mathrm{~min}$ ) and the rumen fluid was strained from its contents through gauze into a test tube with preservative. Five $\mathrm{ml}$ of the rumen fluid were taken from each animal and were mixed with $5 \mathrm{ml}$ of $10 \%$ formaldehyde.

Infusorial concentrations in the rumen fluid were assessed by counting in a Fuchs-Rosenthal counting chamber at $100 \times$ magnification. The resulting number of infusoria was re-calculated to $1 \mathrm{ml}$ volume and used as a basic statistical information for subsequent processing.

For those groups of samples where some differences were expected, the mean and standard deviation were calculated. Significance of differences was tested by nonparametric Mann-Whitney $U$ test at $\mathrm{n}<12$ or parametric $\mathrm{t}$-test at $\mathrm{n}=12$.

\section{Results}

Infusoria were detected in all of the analysed rumen fluid samples. Their concentrations ranged from 118 to $927 \times 10^{3}$ per ml. The final infusorial concentrations observed in the vegetation period and in the winter season are presented in Table 2.

Table 2

Infusorial concentrations in the rumen fluid of red deer, fallow deer, roe deer and mouflon in the vegetation period and in the winter, infusoria per $\mathrm{ml}\left(\times 10^{3}\right)$

\begin{tabular}{|l|c|c|c|c|c|c|c|c|c|c|}
\hline \multirow{2}{*}{$\begin{array}{l}\text { Game } \\
\text { species }\end{array}$} & \multicolumn{4}{|c|}{ Vegetation period } & \multicolumn{5}{c|}{ Winter season } \\
\cline { 2 - 13 } & $\mathrm{n}$ & $\min$ & $\mathrm{X}$ & $\max$ & $\mathrm{SD}$ & $\mathrm{n}$ & $\min$ & $\mathrm{X}$ & $\max$ & SD \\
\hline Red deer & 30 & 547 & 718 & 927 & 108 & 30 & 128 & 409 & 565 & 115 \\
\hline Fallow deer & 15 & 257 & 519 & 726 & 121 & 13 & 184 & 349 & 457 & 85 \\
\hline Roe deer & 52 & 118 & 572 & 785 & 111 & 13 & 118 & 426 & 865 & 201 \\
\hline Moufflon & 12 & 385 & 647 & 865 & 112 & 13 & 122 & 438 & 675 & 138 \\
\hline
\end{tabular}

In the winter season, the infusorial concentration in all four studied hoofed game species was significantly lower $(\mathrm{p}<0.01)$ than in the vegetation period. The least difference $(26 \%)$ was observed in roe deer, the largest $(43 \%)$ in red deer. In fallow deer the infusorial concentration in the winter season decreased by $33 \%$, in moufflon by $32 \%$, respectively.

Table 3

Mean values of infusorial concentrations in the rumen fluid of red deer and roe deer in three age categories, infusoria per $\mathrm{ml}\left(\times 10^{3}\right)$

\begin{tabular}{|l|r|r|r|r|r|r|}
\hline $\begin{array}{l}\text { Age } \\
\text { category }\end{array}$ & CE1 & CE2 & CE3 & CC1 & CC2 & CC3 \\
\hline & \multicolumn{7}{|c|}{ Vegetation period } \\
\hline $\mathrm{n}$ & 8 & 14 & 8 & 15 & 12 & 25 \\
\hline $\mathrm{X}$ & 708 & 741 & 689 & 581 & 590 & 558 \\
\hline $\mathrm{SD}$ & 122 & 102 & 93,7 & 96,4 & 94,3 & 121 \\
\hline & \multicolumn{7}{|c|}{ Winter season } \\
\hline $\mathrm{n}$ & 13 & 12 & 5 & 4 & 5 & 4 \\
\hline $\mathrm{X}$ & 384 & 440 & 400 & 568 & 402 & 314 \\
\hline SD & 131 & 108 & 63,7 & 216 & 223 & 35 \\
\hline
\end{tabular}

No difference in the mean infusorial concentration per ml of the rumen fluid was found between different age categories (Table 3 ) and sexes (Table 4 ) in red deer and roe deer in either the vegetation period or in the winter season ( $p>0.05$ for all cases). 
Table 4

Mean values of infusorial concentrations in rumen fluid of male $(\mathrm{M})$ and female $(\mathrm{F})$ red deer, fallow deer, roe deer and moufflon in the vegetation period and in the winter season, infusoria per $\mathrm{ml}\left(\times 10^{3}\right)$

\begin{tabular}{|c|c|c|c|c|c|c|c|c|}
\hline & \multicolumn{8}{|c|}{ Vegetation period } \\
\hline Species & \multicolumn{2}{|c|}{$\mathrm{CE}$} & \multicolumn{2}{|c|}{ DD } & \multicolumn{2}{|c|}{$\mathrm{CC}$} & \multicolumn{2}{|c|}{ OM } \\
\hline Sex & $\mathrm{M}$ & $\mathrm{F}$ & $\mathrm{M}$ & $\mathrm{F}$ & $\mathrm{M}$ & $\mathrm{F}$ & $\mathrm{M}$ & $\mathrm{F}$ \\
\hline $\mathrm{n}$ & 10 & 18 & 8 & 7 & 36 & 16 & 7 & 6 \\
\hline $\mathrm{x}$ & 730 & 712 & 505 & 534 & 568 & 581 & 671 & 613 \\
\hline \multirow[t]{2}{*}{ SD } & 119 & 102 & 134 & 110 & 129 & 48,2 & 99,6 & 114 \\
\hline & \multicolumn{8}{|c|}{ Winter season } \\
\hline Species & \multicolumn{2}{|c|}{$\mathrm{CE}$} & \multicolumn{2}{|c|}{ DD } & \multicolumn{2}{|c|}{$\mathrm{CC}$} & \multicolumn{2}{|c|}{ OM } \\
\hline Sex & $\mathrm{M}$ & $\mathrm{F}$ & $\mathrm{M}$ & $\mathrm{F}$ & M & $\mathrm{F}$ & M & $\mathrm{F}$ \\
\hline $\mathrm{n}$ & 10 & 20 & 7 & 6 & - & 13 & 5 & 7 \\
\hline $\mathrm{X}$ & 463 & 382 & 361 & 340 & - & 426 & 522 & 367 \\
\hline SD & 67,6 & 124 & 90,6 & 80,0 & - & 201 & 96,2 & 131 \\
\hline
\end{tabular}

In the winter, infusorial concentration in the rumen fluid of roe deer from mountain environment was considerably lower than in animals from other localities $(\mathrm{p}<0.01)$. In samples obtained during the vegetation period, no significant differences were observed $(p>0.05)$ (Table 5).

Table 5

Mean values of infusorial concentrations in the rumen fluid of roe deer from mountain regions (CCh) and roe deer from other regions $(\mathrm{CCn})$ in the vegetation period and in the winter season, infusoria per $\mathrm{ml}\left(\times 10^{3}\right)$

\begin{tabular}{|l|c|c|c|c|c|c|}
\hline \multirow{2}{*}{} & \multicolumn{3}{|c|}{ Vegetation period } & \multicolumn{3}{c|}{ Winter season } \\
\cline { 2 - 7 } & $\mathrm{n}$ & $\mathrm{X}$ & $\mathrm{SD}$ & $\mathrm{n}$ & $\mathrm{X}$ & $\mathrm{SD}$ \\
\hline $\mathrm{CC} \mathrm{n}$ & 25 & 546 & 124 & 5 & 693 & 108 \\
\hline $\mathrm{CC} \mathrm{h}$ & 27 & 598 & 88,0 & 8 & 307 & 165 \\
\hline
\end{tabular}

Differences in infusorial concentrations between individual game species

In the vegetation period, the highest mean infusorial concentration in the rumen fluid was found in red deer $\left(718 \times 10^{3}\right.$ per $\left.\mathrm{ml}\right)$, the lowest in fallow deer $\left(519 \times 10^{3}\right.$ per ml $)($ Table 2$)$. The number of infusoria was significantly higher in red deer than in fallow deer $(\mathrm{t}=5.46$; $\mathrm{df}=43 ; \mathrm{p}<0.001)$, higher in red deer than in roe deer $(\mathrm{t}=5.74 ; \mathrm{df}=80 ; \mathrm{p}<0.001)$ and higher in moufflon than in fallow deer $(\mathrm{t}=2.72 ; \mathrm{df}=25 ; \mathrm{p}<0.05)$. Differences in number of protozoa between red deer and moufflon, fallow deer and roe deer and between roe deer and moufflon were not significant $(\mathrm{p}>0.05)$. In the winter season, the mean number of infusoria per $\mathrm{ml}$ of the rumen fluid ranged in different game species from 349 to $438 \times 10^{3}$ per ml. However, the differences in their concentrations were not significant $(\mathrm{p}>0.05)$.

Studied game species belong to three different feeding types according to Hofmann (1989). Roe deer is a concentrate selector, red deer and fallow deer belong to intermediate feeders and mouflon is a grass and roughage eater. In the studied material, no particular association was detected between infusorial concentration in the rumen fluid and feeding type of the animal. In the vegetation period, infusorial concentrations were considerably different in game species of the same feeding type (red deer and fallow deer), on the contrary, the differences between different feeding types (roe deer and moufflon) were not significant.

\section{Discussion}

The infusorial concentration in the rumen fluid of ruminants is variable. Very wide range has been reported, most often between $500 \times 10^{3}$ and $1000 \times 10^{3}$ infusoria per ml of rumen fluid. Bergner and Ketz (1975) report infusorial concentrations of approximately 1000 $\times 10^{3}$ per ml, Jagoš and Dvořák (1982) from 200 to $500 \times 10^{3}$, Zelenka (1990) from 0 to $1000 \times 10^{3}$, Crha (1969) from 17 to $635 \times 10^{3}$, Bartoš $(1987)$ from $10^{3}$ to $10^{7}$, 
Wejde mar (1996) from $10^{3}$ to $10^{8}$ infusoria per ml of the rumen fluid in different ruminant species. In the material used for this study, infusorial concentrations were within the range of the mean values as mentioned above.

In free-living ruminants, significant differences exist between food quality in the vegetation period and in the winter season (Homolka 1995, 1996; Heroldová 1996 and others). During the winter season, both quantity and quality of food supply are restricted and any differences in diet composition between different hoofed game species of different feeding types disappear (Žilinec 1995). Infusorial concentration depends on food supply changes. Church (1976), Dvořák (1979) and others report that diet composition has significant influence on both the number and species composition of rumen protozoa. Holub et al. (1969) states that starving has a great influence on infusorial concentration and total defaunation of rumen occurs in 4 - 6 days. The results of the present study confirmed fluctuation of infusorial concentration and its association with food supply. In the winter season, significant decrease of infusorial concentration per $\mathrm{ml}$ of rumen fluid was observed in all four studied game species.

Different opinions on the importance of infusoria in rumen have been published. Holub et al. (1969) states that infusoria do not contribute directly to cellulose digestion. On the other hand, Bergner and Ketz (1975) concede some infusoria of genus Diplodinium the ability to decompose cellulose. Bartoš (1987) reports that the ability to digest cellulose was shown in Entodiniomorpha but at the same time he adds that the obtained results might have been influenced by two factors: either the infusoria ingested the cellulolytic bacteria, or the protozoa utilize only dissolvable plant tissue compounds and excrete the indigested fractions. Deutsch et al. (1998) proved an interaction between infusorial concentration in rumen and cellulolytic activity of its contents. Hintn aus (1996) reports that of all cellulose decomposing infusoria abundant in other game species, only one species can be found in roe deer (not regularly), which could explain the fact that roe deer is not capable of cellulose digestion and therefore does not perform bark stripping. This hypothesis disagrees with the results of Crha (1990) and others, who have discovered up to eight infusoria species members in rumen of roe deer.

Most authors agree that infusoria in rumen of ruminants are not essential and that any decrease of their number or even their total elimination does not affect the animals to a great degree (Church 1976; Zelenka 1990). However, their elimination changes the course of digestive processes. The effects of this defaunation vary due to their dependence on the feed ration composition and on physiological demands of the organism. In this case, if game is fed on roughage, the volume of organic matter digestion decreases (B artoš 1987).

In comparison to the effect of bacteria on digestion, that of infusoria is much less pronounced. Nevertheless, their activity in rumen is not non-significant and, therefore, it would be useful to gain more information on the differences between game species and the factors that influence their concentration, and contribute to clarification of their function in the ruminal ecosystem. Evaluation of the infusoria population evolution dynamics in the vegetation period and in the winter season can help to refine the knowledge of adaptations of the whole digestive tract of free-living ruminants and deserves further study.

\section{Početnost nálevníků v bachorové štávě jelení, daňčí, srnčí a mufloní zvěře}

U jelení, daňčí, srnčí a mufloní zvěře pocházející ze severní a jižní Moravy byl sledován počet nálevníků $\mathrm{v}$ bachorové tekutině ve vegetačním a zimním období. Bylo vyšetřeno celkem 178 ulovených jedinců. Početnost nálevníků byla stanovena počítáním na FuchsRosenthalově komůrce. Počet nálevníků se ve vegetačním období pohyboval u jelena od 547 do 927 tisíc, srnce od 118 do 785 , daňka od 257 do 726 a muflona od 385 do 865 tisíc 
nálevníků na $1 \mathrm{ml}$ bachorové tekutiny. V zimním období byly oproti vegetačnímu zjištěny průkazně nižší počty nálevníků u všech čtyř sledovaných druhů. Typ lokality ovlivňoval početnost nálevníkủ jen v zimním období. Množství nálevníků nebylo ovlivněno pohlavím ani věkem sledovaných zvířat.

\section{Acknowledgements}

I wish to thank Dr. Miloslav Homolka for valuable suggestions and continuous support during work on the present study. This study was supported by the Grant Agency of the Czech Republic, Grant No. 206/97/0172.

\section{References}

BARTOŠ, S. 1987: Mikrobiologie a biochemie trávení v bachoru přežvýkavců. Studie ČSAV, 10, Praha, Academia, $184 \mathrm{p}$.

BERGNER, H., KETZ, H. A. 1975: Trávenie, resorpcia a intermediárna látková premena u hospodárskych zvierat. Príroda, Bratislava, $416 \mathrm{p}$.

CRHA, J. 1969: Infusoria of the Rumen of Fattened Cows. Acta vet. Brno 38: 491-495

CRHA, J. 1972: Rumen Ciliates in Fallow Deer (Dama dama L.). In: Náměšt Preserve. Acta vet. Brno 41: $355-362$

CRHA, J. 1990: Bachoroví nálevníci u některých našich divoce žijících přežvýkavců. Autoreferát přednášky, Scripta Medica 63: 515

CRHA, J., HRABĚ, V., KOUBEK, P. 1985: Rumen Ciliate fauna in the Chamois (Rupicapra rupicapra L.). Acta vet. Brno 54: 141-147

DEHORITY, B. A. 1997: Rumen ciliate protozoa in Australian red deer (Cervus elaphus L.). Archiv-für Protisstenkunde 148: 157-165

DEUTSCH, A., LECHNER, D. M., WOLF, G. A. 1998: Activity of cellulolytic enzymes in the contens of reticulorumen and caecocolon of roe deer (Capreolus capreolus). Comp. Biochem. Physiol. 119: 925-930

DVOŘÁK, R. 1979: Využití některých fyzikálně chemických a biologických vlastností bachorové tekutiny při diagnostice bachorových poruch.Thesis VŠV, $231 \mathrm{p}$.

DVORÁK, R. 1994: Fyziologie trávení v bachoru. In: Nový systém výživy a techniky krmení skotu. VŠZ Brno: 3-8

ENZINGER, W., HARTFIEL, W. 1998: The effects of increased energy and protein contents in the feed on the fermentation products, fauna and mucous membranes of the rumen of wild ruminants (Fallow deer, Roe deer) in comparsion to domestic ruminants (Sheep/goats). Ztschr. für Jagdwissenschaft 44: 201-220

HEROLDOVÁ, M. 1996: Potravní ekologie srnce obecného (Capreolus capreolus), kozy bezoárové (Capra aeagrus) a muflona (Ovis musimon) v biosférické reservaci Pálava. Thesis, Akademie věd české republiky, ústav ekologie krajiny, Brno, 179 p.

HINTNAUS, J. 1996: Výživa a přikrmování srnčí zvěře. Sborník referátů konference Srnčí zvěř 1996: 36-44

HOFMANN, R. R. 1989: Evolutionary steps of ecophysiological adaptation and diversification of ruminants: a comparative view of their digestive systém. Oecologia 78: 443-457

HOLUB, A. (Ed.) 1969: Fyziologie hospodářských zvířat. Praha, SZN, pp. 444-488

HOMOLKA, M. 1995: The diet of Cervus elaphus and Capreolus capreolus in deforested areas of the Moravskoslezské beskydy mountains. Folia Zool. 44: 227-236

HOMOLKA, M. 1996: Foraging strategy of large herbivores in forest habitats. Folia Zool. 45: 127-136

CHURCH, D. C. 1976: Digestive Physiology and Nutrition of Ruminants. Metropolitan Printing, Portland, Oregon, $350 \mathrm{p}$.

JAGOŚ, P., DVOŘ́KK, R. 1982: Poruchy metabolických procesov v bachore. In: JELÍNEK, P., DVOŘÁK, R., JELÍNEK, K. 1989: Metabolický profil bachorové tekutiny beranů v průběhu odchovu. Acta Univ. Agric. 37: 203-210

KUBÍKOVÁ, M. 1935: Infusorien aus dem Pansen von Cervus elaphus L. Zool. Anz. 111: 175- 77

SLÁDEČEK, F. 1947: Ophryoscolecidae z bachoru jelena (Cervus elaphus L.) daňka (Dama dama L.) a srnce (Capreolus capreolus L.). Věstník Čsl. Zool. Spol. 10: 201-231

SZAKÁCS, J. CHOVANEC, J., SOMMER, A., ČEREŠŇÁKOVÁ, Z., VAVROVIČOVÁ, I. 1995a: Vplyv rozdielnej výživy na fermentáciu a degradovatelnost živín v bachore hovädzieho dobytka a jeleňov. Project report 02-04-02, VÚŽ V Nitra, pp. 7-22

SZAKÁCS, J., CHOVANEC, J., SOMMER, A., VAVROVIČOVÁ, I. ŽITŇAN, R., KARTUSEK, V. 1995b: Vplyv rozneho pomeru lůčneho sena a krmneho doplnku na tráviace pochody v predžalúdkoch jeleňov. Project report 02-514-32/05-02, VÚŽV Nitra, pp. 3- 9

WEJDEMAR, K. 1996: The Role of Growth Factors in the Bacterial Ecology of the Rumen. Thesis, Swedish University of Agricultural Sciences. Upsala, pp. 8-12

ZELENKA, J. 1990: Základy výživy a krmení přežvýkavců. Brno, VŠZ, 81 p.

ŽILINEC, J. 1995: Sezónne zmeny vo výžive jelenej a srnčej zveri na Polane a Sitne. Folia Venatoria 25: 19- 29 